\title{
Studies on the Processing and Preservation of Dragon Fruit (Hylocereus undatus) Jelly
}

\author{
M. Z. Islam*, M. T. H. Khan, M. M. Hoque and M. M. Rahman \\ Department of Food Engineering and Tea Technology, Shahjalal University of Science and \\ Technology, Sylhet, Bangladesh \\ *Corresponding author and Email: zohurulislam.engg@gmail.com
}

Received: 05 April $2012 \quad$ Accepted: 15 November 2012

\begin{abstract}
The aim of the study was to analyze the proximate composition of Dragon fruit (Hylocereus undatus) and to develop dragon fruit jelly to assess its prospect in marketability. The proximate analysis showed moisture $87.90 \pm 0.03 \%$, ash $87.90 \pm 0.03 \%$, reducing sugar $4.50 \pm 0.04 \%$, non-reducing sugar $3.50 \pm 0.01 \%$, total sugar $8.00 \pm 0.01 \%$, total soluble solid $11 \pm 0.13 \%$, pH $4.20 \pm 0.02 \%$, acidity $0.45 \pm 0.01 \%$ and vitamin-C $9.90 \pm 0.04 \%$. Then the dragon fruit jelly was prepared with standard formulation $(0.05 \%, 0.1 \%$ and $1.5 \%$ of pectin) was analyzed for its nutritional composition with standard method. The three samples contained more or less similar nutritional compositions. The products were stored at ambient temperature $\left(27{ }^{0} \mathrm{C}\right.$ to $\left.34{ }^{\circ} \mathrm{C}\right)$ for a period of 6 months and quality parameters were assessed. During storage the changes in color, flavor, odor, TSS and $\mathrm{pH}$ was observed. No special change of ingredients was found during first 4 months of storage and a little change of $\mathrm{pH}$ was observed after $4^{\text {th }}$ months. A taste panel consisting of 10 panelists adjudged the acceptability of the samples. The consumer preferences were measured by statistical analysis. Among the samples jelly containing $1.5 \%$ pectin secured the highest score for color, flavor, turbidity and overall acceptability.
\end{abstract}

\section{Key words: Dragon fruit, jelly, vitamin C, pectin, sensory quality}

\section{Introduction}

A pitaya or pitahaya is the fruit of several cactus species, most importantly of the genus Hylocereus (sweet pitayas). These fruits are commonly known as dragon fruit. Currently it is being cultivated in at least 22 countries in the tropics including Australia, Cambodia, China, Malaysia, Thailand, and Srilanka and also in Bangladesh (Mizrahi and Nerd, 1999; Nerd et al., 2002b; Nobel and Barerra, 2002). The dragon fruit cactus fruit is perhaps most common as the red dragon fruit (the red dragon fruit cactus fruit has red flesh or red pulp). Sweet pitayas have a creamy pulp and a delicate aroma. To prepare a pitaya for consumption, the fruit is cut open to expose the flesh. The fruit's texture is sometimes likened to that of the kiwifruit due to the presence of black, crunchy seeds. The flesh, which is eaten raw, is mildly sweet and low in calories. The seeds are eaten together with the flesh, have a nutty taste and are rich in lipids (Abdul Azis Ariffin et al., 2008). Dragon fruit features a mouth watering light sweet taste, an intense shape and color, not forgetting its outstanding flowers. In addition to being tasty and refreshing, this beautiful fruit boasts of a lot of water and other vital minerals with varied nutritional ingredients. Processed dragon fruit products are rarely available in our markets and very little work has been done on processing of dragon fruit in our country. Food processing 
industries are in developing stage in Bangladesh and consumption of processed fruit products is gradually becoming popular. A number of locally processed fruit products are now available in the market. If quality products from dragon fruit are developed, it might be welcomed by the consumers who have affinity for dragon fruit round the year. Dragon fruit is rich in nutritive value. The dragon fruit pulp contains $82.5-83 \%$ moisture, $0.16-0.23 \%$ protein, 0.21 $0.61 \%$ fat, $0.7-0.9 \%$ fiber, $6.3-8.8 \mathrm{mg}$ calcium, 30.2-36.1 mg phosphorous, 0.5-061 mg iron, 8-9 mg vitamin C (Taiwan Food Industry Development and Research Authorities, 2005). So the scope of utilizing dragon fruit remains bright in Bangladesh. Dragon fruit contains 0.20$1.04 \%$ (Kanjana et al., 2006) pectin, so its jam and jelly usually call for added pectin. Pectin contents are known as pectic polysaccharide which helps gellification in proper concentration of $\mathrm{pH}$ and sugar. Different concentrations of added pectin bring variability in organoleptic and physico-chemical properties of jam and jelly. Development of varieties of products like jam, jelly and squash utilizing local produces is critically important for expanding the country's developing food industries. Conversely, product diversification or preservation methods are not undertaken too much for this fruit in Bangladesh. Therefore the present study was carried out to achieve the following objectives: (i) To analyze the proximate composition of Dragon Fruits and to develop jelly and (ii) To assess the nutritional quality, sensory attributes and storage stability of the prepared jelly at ambient temperature of Bangladesh.

\section{Materials and Methods}

The experiment was conducted in the laboratory of "Department of Food Engineering and Tea Technology", Shahjalal University of Science and Technology, 2011-2012. The Dragon fruit (Hylocereus undatus) was collected from the local market. The major ingredients for the preparation of products were sugar, citric acid, pectin and other chemicals were used from the laboratory store.

\subsection{Extraction of dragon fruit juice}

The fully ripe healthy and fresh dragon fruit was washed thoroughly with potable water and the skin was removed by a knife. The seeds were removed and then dragon fruit was blended by a blending machine. The juice thus obtained was preserved by freezing.

\subsection{Chemical analysis of dragon fruit juice}

The method described in AOAC (2004) for determining moisture was used for moisture estimations in dragon fruit products where the temperature was maintained at $100-105^{\circ} \mathrm{C}$ for 24 hours. Temperature of drying was reduced because fruit sugars are mainly fructose which might be decomposed to a great extent when heated to $100{ }^{\circ} \mathrm{C}$ and may give an unrealistic value of moisture content. The acidity was determined by titration using standard sodium hydroxide solution and expressed as anhydrous citric acid and $\mathrm{pH}$ was measured by a $\mathrm{pH}$ meter. The ascorbic acid content in the products was estimated by titrimetic method as summarized by Rangana (2003) using 2-6, dichlorophenol endophenol dye and sugar by Lane and Eynon (1923) method. AOAC method (2004) was used to determine ash and crude fat content of the sample. Total soluble solids (TSS) were determined by the method described by Rangana (2003).

\subsection{Formulation of dragon fruit product jelly}

The Jelly prepared from Dragon fruit with different formulation was coded as: Jelly A, B, C. The formulation of different dragon fruit Jelly products was shown in Table 1.

\subsection{Processing of dragon fruit jelly}

Four hundred fifty gram filtered dragon fruit juice, $550 \mathrm{~g}$ sugar, $5 \mathrm{~g}$ citric acid was used to make $1 \mathrm{~kg}$ dragon fruit jelly. In addition 5, 10 and $15 \mathrm{~g}$ of pectin (High Methoxy pectin: $\mathrm{DE}>50$ ) were added in three different formulations. Pectin was mixed with equal amount sugar in a stainless steel pot. The remaining sugar was mixed with dragon fruit 
Table 1. Formulations of Dragon Fruit Jelly (1000 g)

\begin{tabular}{llll}
\hline \multicolumn{1}{c}{ Ingredients } & A & B & C \\
\hline Dragon fruit juice (g) & 450 & 450 & 450 \\
Sugar (g) & 550 & 550 & 550 \\
Pectin (\%) & 0.5 & 1.0 & 1.5 \\
Citric acid (g) & 5 & 5 & 5 \\
KMS (ppm) & 300 & 300 & 300 \\
\hline
\end{tabular}

juice and heated until the TSS become nearer to $55^{\circ}$ brix. Then sugar mixed pectin was added and continued the heating until TSS becomes nearer to $58^{\circ}$ brix. The citric acid was added and continued the heating. When TSS of the jelly becomes $67^{\circ}$ brix, then the KMS was added and then poured in a sterilized glass bottle and parafinning the cap.

\subsection{Storage studies}

Processed Dragon fruit jellies were stored at ambient temperature $\left(27{ }^{0} \mathrm{C}\right.$ to $\left.34{ }^{0} \mathrm{C}\right)$ for a period of 6 months and quality parameters like the changes in TSS, $\mathrm{pH}$, color, flavor and turbidity were observed. The analyses of the parameters were done according to standard analytical methods summarized by AOAC (2003) and Rangana (2003).

\subsection{Sensory analysis of dragon fruit jelly}

Dragon fruit jellies were analyzed for sensory characteristics. Sensory quality characteristics were evaluated by a panel of 10 semi-trained members using a 9-point Hedonic scale. The Dragon fruit jellies were evaluated for their color, flavor, turbidity, and overall acceptability.

\subsection{Statistical analysis}

The experimental data were statistically analyzed by Randomized Complete Block Design (RCBD) using MSTAT statistical software (Version 5.4.1) in a microcomputer. The mean values adjusted by Duncan's Multiple Range Test (DMRT) (Duncan, 1951).

\section{Results and Discussion}

The results of various experiments conducted during the study period are summarized below:

\subsection{Composition of dragon fruit juice}

The composition of fresh dragon fruit juice such as moisture, TSS, reducing sugar, non-reducing sugar, total sugar, and ash, $\mathrm{pH}$, acidity and vitamin $\mathrm{C}$ contents recorded in Table 2 . The results obtained are in good agreement with those of ICBF (1992) and Morton (1987). The result of vitamin C content $10.90 \mathrm{mg} / 100 \mathrm{~g}$ supported by Teddy (2008) who reported 9 $\mathrm{mg} / 100 \mathrm{gm}$, beside this $\mathrm{pH}$ (4.20) and acidity (0.45) also closely related.

\subsection{Chemical composition of dragon fruit jelly}

Vitamin-C content in dragon fruit was found to be very low compared to other citrus fruits. It was further reduced in jellies prepared from dragon fruit juice because most of the vitamin-C present in the pulp was destroyed during long heating at high temperature. The compositions of dragon fruit jelly were analyzed for moisture content, vitamin-C, acidity, TSS, $\mathrm{pH}$ and sugar. There were three jelly products $(\mathrm{A}, \mathrm{B}, \mathrm{C})$ each differing in pectin content $0.5 \%, 1.0 \%$, and $1.5 \%$ respectively. The nutritional composition of dragon fruit jellies were more or less similar that the values found by Glicksman (1983). The result for each of the sample, the mean result and the SD values are shown in Table 3. 
Table 2. Composition of fresh dragon fruit juice

\begin{tabular}{lc}
\hline Parameters & Dragon fruit pulp \\
\hline Moisture (\%) & $87.90 \pm 0.03$ \\
Ash (\%) & $0.50 \pm .02$ \\
Reducing sugar (\%) & $4.50 \pm 0.04$ \\
Non-reducing sugar (\%) & $3.50 \pm 0.01$ \\
Total sugar (\%) & $8.00 \pm 0.01$ \\
TSS & $11.0 \pm 0.03$ \\
pH & $4.20 \pm 0.02$ \\
Acidity $(\%)$ & $0.45 \pm 0.01$ \\
Vitamin-C $(\mathrm{mg} / 100 \mathrm{~g})$ & $9.90 \pm 0.04$ \\
\hline
\end{tabular}

The values are mean \pm S.D of three independent determinations.

Table 3: Chemical composition of dragon fruit jelly

\begin{tabular}{llcc}
\hline \multirow{2}{*}{ Parameters } & \multicolumn{3}{c}{ Percentage $(\%)$} \\
\cline { 2 - 4 } & $30.12 \pm 0.15^{\mathrm{a}}$ & $28.96 \pm 0.05^{\mathrm{b}}$ & $29.10 \pm 0.08^{\mathrm{b}}$ \\
\hline Moisture (\%) & $0.59 \pm 0.01^{\mathrm{b}}$ & $0.62 \pm 0.01^{\mathrm{a}}$ & $0.62 \pm 0.01^{\mathrm{a}}$ \\
Ash (\%) & $27.42 \pm 0.07^{\mathrm{b}}$ & $27.36 \pm 0.01^{\mathrm{b}}$ & $28.04 \pm 0.03^{\mathrm{a}}$ \\
Reducing Sugar (\%) & $37.46 \pm 0.04^{\mathrm{b}}$ & $36.99 \pm 0.01^{\mathrm{c}}$ & $38.06 \pm 0.12^{\mathrm{a}}$ \\
Non-Reducing Sugar (\%) & $64.97 \pm 0.06^{\mathrm{b}}$ & $64.01 \pm 0.01^{\mathrm{c}}$ & $65.02 \pm 0.07^{\mathrm{a}}$ \\
Total Sugar (\%) & $4.20 \pm 00^{\mathrm{a}}$ & $4.20 \pm 00^{\mathrm{a}}$ & $4.20 \pm 00^{\mathrm{a}}$ \\
pH & $0.44 \pm 0.01^{\mathrm{b}}$ & $0.46 \pm 0.01^{\mathrm{a}}$ & $0.45 \pm 0.01^{\mathrm{ab}}$ \\
Acidity (\%) & $66.67 \pm 0.57^{\mathrm{a}}$ & $67.00 \pm 0.57^{\mathrm{a}}$ & $67.00 \pm 0.57^{\mathrm{a}}$ \\
TSS & $2.79 \pm 0.01^{\mathrm{a}}$ & $2.77 \pm 0.01^{\mathrm{a}}$ & $2.61 \pm 0.01^{\mathrm{b}}$ \\
\hline Vitamin C (mg/100 gm) & &
\end{tabular}

The values are mean \pm S.D of three independent determinations. The means with different superscripts in a row differ significantly $(\mathrm{p} \leq 0.05)$. 


\subsection{Storage studies of dragon fruit jelly}

During storage the changes in color, flavor, texture, TSS and $\mathrm{pH}$ was observed on a one month interval. All parameters of the product were acceptable up to $4^{\text {th }}$ month of storage, the quality of the products was deteriorated like as off flavor produced and $\mathrm{pH}$ decreased for all the products. It reveals that the shelf life of these products is not more than 4 months (Table 4).

3.4. Sensory evaluation of the dragon fruit jelly The samples of dragon fruit jelly were subjected to sensory evaluation. Ten judges evaluated the color, flavor, texture and overall acceptability of the three samples. The mean scores for color, flavor, texture and overall acceptability of different samples are presented in Table 5.
The analysis indicated that there were significant differences in color, those samples at $\mathrm{p} \leq 0.05$. With the increasing level of pectin the texture quality of the dragon fruit jelly increased. The flavor of the dragon fruit jelly sample A and C are similar where as the jelly containing $0.5 \%$ pectin is significantly differed from jelly prepared from $1 \%$ pectin statistically. In the turbidity content the jelly prepared from $1.5 \%$ pectin secured the highest score and significantly differ from others where the jelly samples A and $\mathrm{B}$ are not significantly differed. This is due to the low pectin content in fresh dragon fruit pulp (Morton, 1987). In case of overall preference among the samples, analysis showed that there was significant $(\mathrm{p}<0.05)$ difference and all the 3 samples were not equally acceptable.

Table 4: Storage study of dragon fruit jelly

\begin{tabular}{|c|c|c|c|c|c|c|c|}
\hline \multirow{2}{*}{$\begin{array}{l}\text { Period of } \\
\text { storage } \\
\text { (months) }\end{array}$} & \multirow{2}{*}{$\begin{array}{l}\text { Sample } \\
\text { Code }\end{array}$} & \multicolumn{3}{|c|}{ Observation } & \multirow{2}{*}{$\begin{array}{l}\text { TSS } \\
\%\end{array}$} & \multirow{2}{*}{$\mathrm{pH}$} & \multirow{2}{*}{ Remarks } \\
\hline & & Color & Flavor & Turbidity & & & \\
\hline \multirow{3}{*}{1} & A & Pink & Fresh & Opaque & 66 & 4.20 & Good \\
\hline & $\mathrm{B}$ & Pink & Fresh & Opaque & 67 & 4.20 & Good \\
\hline & $\mathrm{C}$ & Pink & Fresh & Opaque & 67 & 4.20 & Good \\
\hline \multirow{3}{*}{2} & A & Pink & Fresh & Opaque & 66 & 4.20 & Good \\
\hline & B & Pink & Fresh & Opaque & 67 & 4.20 & Good \\
\hline & $\mathrm{C}$ & Pink & Fresh & Opaque & 67 & 4.10 & Good \\
\hline \multirow{3}{*}{3} & A & Pink & Fresh & Opaque & 66 & 4.10 & Good \\
\hline & $\mathrm{B}$ & Pink & Fresh & Opaque & 66 & 4.10 & Good \\
\hline & $\mathrm{C}$ & Pink & Fresh & Opaque & 66 & 4.00 & Good \\
\hline \multirow{3}{*}{4} & $\mathrm{~A}$ & Pink & Fresh & Opaque & 66 & 4.00 & Good \\
\hline & $\mathrm{B}$ & Pink & Fresh & Opaque & 67 & 4.00 & Good \\
\hline & $\mathrm{C}$ & Pink & Fresh & Opaque & 67 & 4.00 & Good \\
\hline \multirow{3}{*}{5} & $\mathrm{~A}$ & Pink & Off flavor & Opaque & 66 & 3.95 & Good \\
\hline & B & Pink & Fresh & Opaque & 66 & 3.90 & Good \\
\hline & $\mathrm{C}$ & Light Pink & Fresh & Opaque & 66 & 3.90 & Good \\
\hline \multirow{3}{*}{6} & A & Pink & Off flavor & Opaque & 66 & 3.85 & Good \\
\hline & B & Light Pink & Off flavor & Opaque & 66 & 3.80 & Good \\
\hline & $\mathrm{C}$ & Light Pink & Fresh & Opaque & 66 & 3.80 & Good \\
\hline
\end{tabular}


Table 5: Mean Sensory scores of dragon fruit jelly

\begin{tabular}{|c|c|c|c|c|c|c|c|c|}
\hline & $\begin{array}{l}\text { Product } \\
\text { Type }\end{array}$ & $\begin{array}{l}\text { Original } \\
\text { Order } \\
\text { of Mean }\end{array}$ & $\begin{array}{l}\text { Product } \\
\text { Type }\end{array}$ & $\begin{array}{l}\text { Ranked } \\
\text { Order of } \\
\text { Mean }\end{array}$ & $\begin{array}{l}\text { Std. } \\
\text { Deviation }\end{array}$ & $\mathrm{P}$ & LSD & $\begin{array}{l}\text { No of } \\
\text { Judges }\end{array}$ \\
\hline \multirow{3}{*}{ Color } & A & $6.70^{c}$ & $\mathrm{C}$ & $7.80^{\mathrm{a}}$ & 0.7888 & \multirow{3}{*}{0.05} & \multirow{3}{*}{0.003} & \multirow{3}{*}{10} \\
\hline & B & $6.90^{\mathrm{b}}$ & B & $6.90^{\mathrm{b}}$ & 0.5676 & & & \\
\hline & $\mathrm{C}$ & $7.80^{\mathrm{a}}$ & A & $6.70^{\mathrm{c}}$ & 0.6749 & & & \\
\hline \multirow{3}{*}{ Flavor } & A & $7.80^{c}$ & A & $7.80^{\mathrm{a}}$ & 0.9486 & \multirow{3}{*}{0.05} & \multirow{3}{*}{0.743} & \multirow{3}{*}{10} \\
\hline & B & $7.10^{\mathrm{b}}$ & $\mathrm{C}$ & $7.30^{\mathrm{ab}}$ & 0.8756 & & & \\
\hline & $\mathrm{C}$ & $7.30^{\mathrm{a}}$ & $\mathrm{B}$ & $7.10^{\mathrm{bc}}$ & 0.8165 & & & \\
\hline \multirow{3}{*}{ Turbidity } & A & $6.70^{c}$ & $\mathrm{C}$ & $7.60^{\mathrm{a}}$ & 1.9550 & \multirow{3}{*}{0.05} & \multirow{3}{*}{0.552} & \multirow{3}{*}{10} \\
\hline & B & $6.80^{\mathrm{b}}$ & B & $6.80^{\mathrm{b}}$ & 1.4337 & & & \\
\hline & $\mathrm{C}$ & $7.60^{\mathrm{a}}$ & A & $6.70^{\mathrm{bc}}$ & 1.1005 & & & \\
\hline \multirow{3}{*}{$\begin{array}{l}\text { Overall } \\
\text { Acceptability }\end{array}$} & A & $6.60^{\mathrm{b}}$ & $\mathrm{C}$ & $7.80^{\mathrm{a}}$ & 1.0328 & \multirow{3}{*}{0.05} & \multirow{3}{*}{0.013} & \multirow{3}{*}{10} \\
\hline & B & $6.80^{\mathrm{c}}$ & A & $6.80^{\mathrm{b}}$ & 0.6992 & & & \\
\hline & $\mathrm{C}$ & $7.80^{\mathrm{a}}$ & B & $6.60^{\mathrm{c}}$ & 0.9189 & & & \\
\hline
\end{tabular}

The values are mean \pm S.D of three independent determinations. The means with different superscripts in a column differ significantly $(\mathrm{p} \leq 0.05)$.

\section{Conclusions}

In Bangladesh dragon fruit is relatively new. Now it is being cultivated in Bangladesh. The study indicates that a good quality value added product could be produced from dragon fruit. As the fruit has some special religious, medicinal, social and nutritive value, it is assumed that it could fetch a good monetary value from the consumers. Therefore, the present study is a sign of bright prospect of processing of dragon fruit products. Further investigation is necessary to study the economic aspects of the products before recommending for commercial production.

\section{Acknowledgement}

The authors gratefully acknowledge the Department of Food Engineering and Tea Technology, Shahjalal University of Science and Technology, Sylhet, Bangladesh for providing the facilities to carry out this research.

\section{References}

Abdul Azis Ariffin, Jamilah Bakar, Chin Ping Tan, Russly Abdul Rahman, Roselina Karim, and Chia Chun Loi. 2008. Essential fatty acids of pitaya (dragon fruit) seed oil. Food Chemistry, 114 (2): 561-564.

AOAC. 2003. Official Methods of Analysis. Association of Official Analytical Chemists, Washington DC, USA.

AOAC. 2004. Official Methods of Analysis. Association of Official Analytical Chemists, Washington DC, USA.

Duncan, D.B. 1951. A significant test for differences between ranked treatments in an analysis of variance. Virginia Journal of Science, 2(9): 171-189.

Glicksman, M. 1983. GumTechnology in the Food Industry. New York, Academic Press, 214-225 pp. 
ICBF. 1992. Table de Composicion de Alimentos. $6^{\text {th }}$ Ed. From: El cultivo de Pitaya Fposicionmiento en elmercardo. http://www.worldagroforestry.org/downlo ads/publications/PDFs/BC07324.PD, 25 November 2011.

Kanjana, M. J., John, A.M., Grayh, S. T. T., Kevin, G. and Elizabeth, A. B. 2006. Total Antioxidant Activity and Fiber Content of Select Florida-Grown Tropical Fruits. Agricularal and food chemistry, 54: 7355-7363.

Lane, J. H., and Eynon, L. 1923. Methods for determination of reducing and nonreducing sugars. Journal of Science, 42: 32-37.

Mizrahi, Y. and Nerd, A. 1999. Climbing and columnar cacti: New arid land fruit crops. Progress in new crops. ASHS Press Alexandria, VA. 56-64 pp.

Morton, J. F. 1987. Fruits of Warm Climates, Strawberry Pear. Florida Flair Books, Miami, 347-348 and 505 pp.
Nerd, A. Tel-Zur, N. and Mizrahi, Y. 2002. Chapter 10: Cactus Pear Fruit Production In: Nobel, P.S. (ed.) Cacti: biology and uses. University of California Press, Berkeley, 163 p.

Nobel, P. S. and de la Berrera, E. 2002. Stem water relations and wet $\mathrm{CO}_{2}$ uptake for hemiepiphytic cactus during short term drough. Environment and Experimental Botany, 48: 129-137.

Ranganna, S. 2003. Hand book of analysis and quality control for fruits and vegetables product. Tata McGraw-Hill publishing company limited. New Delhi, 11-12 pp.

Taiwan Food Industry Develop and Research Authorities 2005. http://swarnabhumi.com/dragonfruit/Healt h_benefits_of_Dragon_Fruit.htm. 18 February 2011.

Teddy, F. Tepora. 2008. Program Leader, CvSU R\&D on Dragon Fruit. Research Center, Cavite State University. Philippines. http://www.agribusinessweek.com/dragon -fruit-enter-the-dragon/ 17 Sep 2008. 